\title{
The Unknown Victims: Hegemonic Masculinity, Masculinities, and Male Sexual Victimisation
}

\author{
by Aliraza Javaid
}

Newcastle University

Sociological Research Online, 22 (1), 1

$<\mathrm{http}: / /$ www.socresonline.org.uk/22/1/1.html>

DOI: $10.5153 /$ sro.4155

Received: 2 May 2016 | Accepted: 21 Nov 2016 | Published: 28 Feb 2017

\begin{abstract}
This paper adopts the theoretical framework of hegemonic masculinity to elucidate and make sense of male sexual victimisation. Critically evaluating the empirical data, which comprises of police officers and practitioners in voluntary agencies $(N=70)$, that this paper offers, I argue that gender expectations, hegemonic masculinities and sexism prevail in societies, state and voluntary agencies. It has been found that, because male rape victims embody subordinate masculinities, they are marginalised as 'abnormal' and 'deviant'. They are, in other words, classified as the 'other' for challenging and contradicting hegemonic masculinity, disrupting the gender order of men. Consequently, male sexual victimisation is not taken seriously in services, policy and practice, whilst the victims of this crime type are relegated in the gender hierarchy. As a result, male rape victims suffer a 'masculinity crisis' in the context of male rape. This paper attempts to open up a dialogue regarding male rape and male sexual assault, to challenge hegemonic masculinity, and to bring male rape 'out of the closet'.
\end{abstract}

Keywords: Policing, Male Rape, Gender Hierarchy, Gender Expectations, Identity

\section{Introduction}

1.1 The focus of this paper is essentially on how gender and masculinity notions affect and shape police and voluntary agencies' understanding and views of male rape[1], rather than the experiences of adult male victims of rape and the perpetrators of this crime. It is important to present some understanding of male rape with the help of theory, advancing theoretical notions and conceptual understandings relating to male sexual victimisation. By doing so, one is able to examine how gender and masculinity overlap with the discourse of male rape, and this will help provide a correct and accurate understanding of male rape and of the many issues associated with it; and will help understand the pattern and nature of male rape from a gender perspective, underpinned by hegemonic masculinity. It is important to draw on the theoretical framework of hegemonic masculinity to help elucidate my research findings that will be presented in this paper. It is important to employ hegemonic masculinity in this paper because male rape is essentially masculine and violent behavior, so by using hegemonic masculinity to help elucidate the conception of male rape and the responses to it by the police and voluntary services for male rape victims, one can help understand the possible negative reactions and responses to male victims of rape. To get a better understanding of male sexual victimisation, and to understand more about male rape discourse through the respondents' perspectives, this paper will be based on the following research questions:

- How do conceptions of male rape shape state and voluntary agencies' attitudes toward, and responses to male victims of rape and sexual violence in Britain?

- How do notions of gender, sexualities and masculinities affect and shape state and voluntary agencies' understanding of male rape and their views of men as victims of rape?

- What roles do gender, sexualities and masculinities play in the discourse of male sexual victimisation? 
participants' views, which can give an understanding of the different roles gender, sexualities and masculinities play in the discourse of male sexual victimisation. Therefore, learning about male rape and male sexual assault and the different issues associated with these phenomena from my respondents' perspectives are key here and are the aims of this paper. With the support of the theoretical framework of hegemonic masculinity, this paper will critically engage with the discourse and language associated with male rape. This language and discourse is gleaned from primary data $(n=70)$, involving police officers, male rape therapists, counsellors, and voluntary agency caseworkers', unveiling their attitudes toward, and responses to male rape victims. My contribution to the field of sexual violence will show how male rape, masculinities, and sexualities are closely linked to each other. Revealing this interconnection will unlock a foci and discussion of the ways in which gender and sexualities intersect with male rape, which is important to examine because male rape is an issue for gender and sexuality scholars and this paper will provide a pervasive account of it being so. In doing so, before setting out the methods, methodology, results and discussion sections, I will first contextualise the issue of male sexual victimisation so as to set the scene. Then, I will discuss the theoretical framework that is employed in this paper to inform the empirical discussions.

\section{Setting the Scene: Understanding and Explaining Male Sexual Victimisation}

2.1 Research on male rape in the UK is lacking in contrast to female rape where it is more extensive. Therefore, I aim to critically explore the subject of male rape in this paper not only to understand the phenomenon, but also to increase awareness of it since it "has remained largely hidden from public view and like female rape, continues to be shrouded in ignorance and misconception" (Rumney 2008: 67). This is a particular problem, due to some research arguing that the police are homophobic and execute homophobic attitudes toward male rape victims (e.g., Stermac et al. 1996; Lees 1997; Gregory and Lees 1999). Although these research studies were conducted over a decade ago, there is no recent research that examines the police responses to male rape victims, other than Rumney (2008, 2009), Abdullah-Khan 2008's recent monograph, and Javaid (2015c, 2016c, 2017).

2.2 Nevertheless, although these recent research studies raise awareness of male rape in the 21st century, what is important to question is the combination of male rape and negative societal attitudes toward homosexuality to date, and whether homosexual male rape victims in particular are subjected to a form of double victimisation. This is important to consider because society labels gay men as 'abnormal', 'deviant' or 'effeminate' due to Western society's rules of masculinity that cannot account for same sex attraction; the concept of the masculine male is reserved for heterosexual men, leaving gay men marginalised and alienated in societies (Connell 2005). Therefore, after gay male rape victims are raped, it is important to explore whether they in addition experience certain problems in securing appropriate treatment from the police because of their sexual orientation. Walker, Archer and Davies (2005) highlight that the issue of sexuality is fundamental to male rape because homophobia negatively influences attitudes to male rape and the handling of male rape cases in the criminal justice system. More recently, Zaleski (2015: 65) supports this, arguing that, "For many male victims of rape, the issue of sexual identity comes into play. Male victims might fear that recounting the trauma will make people believe he is homosexual...Others might believe they are less of a man". Thus, critically examining the police attitudes toward, and responses to male rape victims enables one to identify and understand the issues that male rape victims experience, regardless of their sexual orientation.

2.3 Although support provisions are available for male rape victims in Britain, there are cultural, religious, social, and emotive issues that constrict men from reporting their rape to the police and from getting the support that they need, which means that they are frequently unreferred to appropriate agencies to serve their needs (Badenoch 2015). This is problematic for a number of reasons; for one, these victims may be left isolated, alone and emotionally damaged. Another implication is that societies may continue to deny the existence of male rape, neglecting or overlooking it, which leaves the gender norms and values unchallenged. Stemple and Meyer (2014) recently found a salient issue that maintains misunderstandings regarding male rape: societies' dependence on conventional gender stereotypes. They argue that such traditional gender stereotypes leave societies from assuming that men are the main perpetrators of male rape when they actually found that men are more likely to be sexually victimised by women than other men.

2.4 The critical discussion of evidence will be gleaned from a range of sources throughout this paper.

Through such an analysis, it will be possible to identify trends and issues in police responses to adult sexual assault and male rape. This is important to do because systematic reviews of the literature suggest that male rape myths may inform the delivery of criminal justice services to victims. For example, Abdullah-Khan (2008) argues that the police and some voluntary agencies are embedded with male rape myths; in other words, they maintain inaccurate views about male rape, such as male rape is non-existent or heterosexual men are unable to 
be raped. Lees (1997) argues, however, that all men have the potential to be raped and all types of men can be raped, regardless of their sexual orientation. Because male rape myths dominate state and voluntary agencies, male rape victims are left untreated, isolated, and sidelined (Donnelly and Kenyon 1996; Hodge and Canter 1998; Cohen 2014). Therefore, it is important to critically discuss these agencies because, if the staff members in the agencies hold negative views about male rape, as they may do about female rape, it can be problematic in that they may inadequately respond to and handle male rape victims. Chapleau et al. (2008: 604) "speculate that the same attitudes that function to support rape myths about female victims may also function to support rape myths about male victims."

2.5 Recent research has found that secondary victimisation is prevalent, which refers to attitudes and behaviors that are insensitive, hostile, homophobic and victim blaming by the police (Rumney 2008, 2009). This supports earlier findings from Donnelly and Kenyon (1996), Hodge and Canter (1998), Gregory and Lees (1999), and Lees (1997). The police may cause secondary victimisation when serving male rape victims through homophobia, disbelieving, and hostile responses because they support the male rape myth that 'male rape is solely a homosexual issue' (Walker 2004). More recent research supports this (Jamel 2010), in which it is argued that gay male rape victims are perceived as less legitimate or deserving, determined by police occupational culture. Similarly, according to Rumney (2009), gay male rape victims are less likely to report their rape to the police than heterosexual victims of male rape because of the officers' homophobic attitudes and behaviors emanating from the police occupational culture.

2.6 Carpenter (2009) believes that state agencies always use a woman-focused model of victimisation when responding to male rape victims; in other words, state agencies deal with both female and male rape in the same way. He argues that some male rape victims experience rape differently in comparison to female rape victims. For example, male rape victims may question their masculinity or sexual orientation, as male rape essentially challenges or contradicts men's power, strength, self-reliance, and independence (Clark 2014). There is a lack of research available on whether voluntary agencies are similarly lacking in specific training to deal with male rape victims, although some attempt is being made examining this area of male rape (see Javaid 2016a, b). Therefore, it is important to examine whether state and voluntary agencies perpetuate or dispel male rape myths in contemporary society, and to explore whether this influences the treatment of male rape victims. For female rape victims, we know that female rape myths influence the type of service being delivered to them. For example, if a female rape victim had been drinking, was previously in a sexual relationship with the defendant, willingly went home with the defendant, or somehow 'led him on', then the rape is less likely to be seen as 'real rape' and the female rape victim is disbelieved, making it more likely for the defendant to be acquitted (Temkin and Krahe 2008). It appears that female rape myths negatively influence criminal justice practitioners. Temkin and Krahe (2008) found this, arguing that bias, stereotypes and gender prejudice strongly influence perceptions of female rape, which in turn negatively influence the treatment provided to female rape victims. As a result, they argue, female rape victims are reluctant to engage with the criminal justice system.

2.7 Cohen (2014) argues that male rape victims report at much lower rates in contrast to female rape victims. Thus, it is important to examine state and voluntary agencies' thoughts, beliefs, attitudes, ideas, and views about male rape; if they believe men can be rape victims; how male rape victims compare to female rape victims; and how they handle male rape victims. If male rape myths are present in state and voluntary agencies, it is important to highlight these and attempt to eradicate such myths because they can contribute to the underreporting of male rape (Gregory and Lees 1999). It is, therefore, unclear from this and other existing work whether low reporting reflects state and voluntary agencies' attitudes toward male rape or whether this is due to other factors, such as the responses to male rape by the wider society; in other words, victims' fears about friends and family finding out.

2.8 With a consideration of hegemonic masculinity, this paper will help us to understand why male rape has been widely overlooked and to discover whether social and gender expectations facilitate this neglect. How a man perceives himself as a man and in what ways masculinities are formed within a social and cultural setting are vital to understanding male rape. Feminists have done much to highlight the plight of female rape victims since the 1970s, and many voluntary services have evolved for these female victims, who are coming to terms with the effects of their rape. The rape of adult males, however, has gained very little attention by the public or in social science research literature. There is still no clear societal strategy to tackle male rape in Britain, even though it is estimated that help and support for male rape victims are more than twenty years behind that for female rape victims (Rogers 1998). 


\section{Theoretical Framework}

To inform the theoretical and empirical discussions in this paper, I draw on hegemonic masculinity to make sense of male sexual victimisation from a gender perspective since the application of hegemonic masculinity to male rape has not been applied before. In almost every single data set, there appeared a theme, concept or conception associated with gender and masculinities. Therefore, this paper will draw on recurring themes founded on gender and masculinities, using hegemonic, subordinated, marginalised and complicit masculinities as sociological theoretical frameworks to elucidate such themes and to throw light on the ways in which gender and masculinities notions shape understandings and views of adult male rape. Linked to this aim, this paper will engage with these masculinities that are configurations of practice. It is significant to engage with these masculinities because, by doing so, one can understand how male rape victims can (and do) engage in different configurations in dissimilar settings, contexts and situations. Engaging with different forms of masculinities and comparing them with hegemonic masculinity is important because my data and other research evidence suggest that male rape victims embody a subordinate form of masculinity since their sexual victimisation places them at the bottom of the gender hierarchy, challenging and contradicting hegemonic masculinity and the social ideal of gender. The expectation of hegemonic masculinity shapes state and voluntary agencies' attitudes toward, and responses to male rape victims. Understanding these attitudes and responses through a gender lens will unveil how and in which ways male victims of rape are perceived, treated, responded to, and talked about.

3.2 Masculinities are not a biological fixed category, and so representing many shades and differences of masculinities. It further suggested that masculinities are best thought of as plural, changing, and not static (Connell and Messerschmidt 2005), or as a sociological theory of gender relations (Connell 1987). West and Zimmerman (1987) and Connell (2005) argue that, through gender and power relations, masculinities are formed, relational and so we 'do' gender in culturally specific manners that are normatively appropriate in a given context and setting. 'Doing' gender in this way, then, indicates that gender is a display, meaning that masculinity is enacted differently depending on the context, setting, environment, and situation in which one situates. Gender is always ongoing, accomplishing, and configuring; it is a social practice, indeed, a "process of configuring practice" (Connell 2005: 72. Emphasis in original). This ideology leads Connell to develop a theory of masculinities that comprises of four different masculinities, which are practices that men move within and without or are positioned in by others, that work together to reinforce and differentiate each other: hegemonic masculinity; subordinate masculinity; complicit masculinity; and marginalised masculinity. She stresses that we need to examine the relationship between these masculinities.

3.3 Hegemonic masculinity practices allow people who embody them to maintain advantageous positions in many aspects of everyday life. In doing so, such practices create and legitimate unequal relationships between men and women, and between men with power and with those men without power (or lack of), giving men a dominant place in the gender hierarchy in contrast to women and 'other(ed)' men (see Connell and Messerschmidt 2005). Such hegemonic configurations can be enacted collectively or individually. Subordinate masculinity, which is particularly important to consider in the context of male rape, relates to the subordination of gay men though it does not just relate to gay men because other men can be subordinated by hegemonic configurations in certain contexts; but it is through a display of material practices where gay men are subordinated to heterosexual men, resulting in cultural ramifications, such as abuse, violence and rejection. Homosexual men can (and do), however, enact hegemonic configurations of practice at times. Complicit masculinity refers to men who do not enact hegemonic masculinity practices. As many men are not able to achieve hegemonic masculinity, most men will however benefit from the inherent power associated with the way that hegemonic configurations of practice become embedded within social structures. Connell calls this the patriarchal dividend, meaning "the advantage men in general gain from the overall subordination of women" and these men are also referred to as embodying a "slacker [version] of hegemonic masculinity" (2005: 79). Thus, " [m]en who received the benefits of patriarchy without enacting a strong version of masculine dominance could be regarded as showing a complicit masculinity" (Connell and Messerschmidt 2005: 832). The final social construction of masculinities is referred to as marginalised masculinity, which explains men who are possibly situated authoritatively regarding gender though are relegated in respect of physical stature, class, or race. For example, ethnic minority and black masculinities are often marginalised to the leading 'superior' white race. These four masculinities are configurations of practices, shaped by social and cultural contexts.

3.4 However, there are some important limitations of hegemonic masculinity, which are vital to highlight to address the theoretical void that the article can help to fill. For example, Connell and Messerschmidt (2005: 836) note themselves that, "The concept of multiple masculinities tends to produce a static typology." For Hearn 
(2004), hegemonic masculinity is blurred and not certain in its meaning while deemphasizing concepts of domination and power. Collier (1998) states that hegemonic masculinity essentialises the character of men; but, as Connell and Messerschmidt (2005) specify, writers often use the concept of hegemonic masculinity in an essentialist and deterministic fashion without considering its fluid, non-static, and malleable nature. This paper highlights the diverse nature of masculinities that male rape victims can embody depending on social structures, social institutions, and social contexts. Hegemonic masculinities are not fixed entities, as some writers mistakenly believe (e.g., Collier 1998; Hearn 2004); rather, they are "configurations of practice that are accomplished in social action and, therefore, can differ according to the gender relations in a particular social setting" (Connell and Messerschmidt 2005: 836).

Having elucidated the theoretical foundation of this paper that will inform the empirical discussions, the empirical section of this paper then will provide an analysis of masculinities, gender expectations and male rape collectively. It draws on hegemonic, subordinated, marginalised and complicit masculinities, developed by Connell (2005), to make sense of the primary data.

\section{Methods and Methodology}

4.1 This study took place in Britain. After ethical approval was gained from a university research ethics committee, the research commenced with the use of two qualitative research methods: semi-structured interviews and qualitative questionnaires. I begin by discussing the former. In qualitative research, semistructured interviews are the most common method of data collection (Jamshed 2014). This form of interview in qualitative research is in-depth, in that the respondents are requested to respond to prearranged, open-ended questions (ibid.). Through the use of semi-structured interviews, which were audio-recorded and transcribed by the researcher, the research attempted to unravel the adequacy of the participants in meeting male rape victims' needs and to explore any male rape myths that might have been present in such participants' attitudes and views. Semi-structured interviews with male rape counsellors/therapists; voluntary agency workers; Sexual Offences Investigation Trained (SOIT) officers; Specially Trained Officers (STOs); rank and file officers, who were situated in Britain, were conducted at either the participants' workplace or mine to further ascertain male rape victims' needs as well as the impact that rape has on male victims. A total of 25 semi-structured interviews were conducted. Each semi-structured interview approximately lasted around 1 hour, giving enough time for me to form trust and rapport with my participants. This interview technique frequently led to fruitful discussions regarding male rape and gave insight into the participants' attitudes, thoughts, beliefs, views, and responses to it that could not have been anticipated with closed-ended questions in surveys.

4.2 The semi-structured interviews were appropriate to use because they easily captured the officers and male rape counsellors/therapists' beliefs, thoughts, views, and attitudes of male rape. This interview technique gave knowledge regarding the workings and experiences of the research participants who deal with male rape cases, so I could examine the competence of the participants. The interviews were an appropriate method of data collection also because some of the research aims needed the critical exploration of personal narratives of the processes by which participants handle male rape cases and victims, and the changes that they had observed whilst employed within the sectors. The interviews helped to ascertain the nature and impact of rape on men's lives and the adequacy of service provisions. The interviews were semi-structured to ensure that some areas were covered in every interview. For example, in the interviews, certain questions about male rape myths were asked, and topics of discussion included issues pertaining to the participants' perceptions of male rape and responses to male rape victims. The interview questions/topics allowed me to consider the ways in which male rape is conceptualised and understood in state and voluntary agencies. The detailed and textual types of information that can be generated from semi-structured interviews make it a viable tool for the qualitative researcher (Jamshed 2014). From a qualitative conceptual framework, semi-structured interviews enabled me to collect in-depth information that could be analysed to help explain and understand the grassroots of my participants' views and perspectives. For the qualitative researcher, semi-structured interviews are flexible and have a lack of strict structure (Edwards and Holland 2013), which helped to create a more informal, conversational, fluid and comfortable interactive process for my participants and me. This interactive approach supports the qualitative conceptual framework, in that understandings and meanings are produced in interactions, which includes the production and reproduction of knowledge (Mason 2002). In effect, coproducing knowledge in this way results in equality in the research relationship between the respondent and researcher (Edwards and Holland 2013).

4.3 In addition, qualitative questionnaires were disseminated to the police and voluntary agencies that were situated in Britain to assess understanding of male rape. The prevalence of male rape myths in 5 police forces was explored using the questionnaire of police attitudes and experiences of male rape cases. The qualitative 
questionnaires were also disseminated to 4 voluntary agencies that deal with male rape. I created two different types of qualitative questionnaires to consider the voluntary and police organisations' different and respective roles. The questionnaires were disseminated to explore the prevalence of myths and misconceptions about male rape among police officers, male rape counsellors, male rape therapists, and voluntary agency caseworkers. In total, 45 qualitative questionnaires out of 80 were filled out, completed and returned. Overall, this study gained a sample size of 70 participants. I ensured that those who were interviewed did not also fill out a questionnaire to prevent skewed data results.

4.4 To inform the development of the semi-structured interview schedule and the qualitative questionnaires, I drew on Abdullah-Khan (2008) in order to shape the types of questions that I might ask. The questionnaires began with demographic questions. Then, they benefited from combining a series of open and closed questions, but predominately included open-ended questions. The closed questions would identify if the respondents had thought about, or were aware of the issues pertinent to male rape and would serve to identify specific aspects of these issues, while open questions would give an indication of general feelings about male rape. Therefore, the participants' reasons for their views and opinions about male rape could be examined by including both closed and open questions, which in turn helped to keep the responses in context while potentially increasing the accuracy of the responses. Including both closed and open questions gave a degree of flexibility to the qualitative questionnaires. According to Edwards and Holland (2013), flexibility is key to, and the basis of qualitative research. Within qualitative research, qualitative questionnaires can provide rich qualitative data because openended questions encourage responses that include stories from people's own experiences, history and biography (Adamson et al. 2004). As a result, I felt that the qualitative questionnaires were in sync with the qualitative conceptual framework, in that they provided a fruitful way in which to investigate male rape and provided triggers to contested or difficult issues embedded in the topic of male rape. They were also adaptable in the sense that the participants could fill them out in their own time, with the participants in control of the flow in responses, giving them greater scope to think through the questions asked. In turn, time for reflection and consideration encourage more well thought out and descriptive answers (Adamson et al. 2004).

4.5 I carried out both questionnaires and the interviews in order to help enhance validity and reliability of the findings. Using triangulation (i.e. using two or more research methods) helped to develop a comprehensive understanding of male rape, and also has been viewed as a qualitative research strategy to test validity through the convergence of information from different sources (Edwards and Holland 2013). My purpose of using triangulation was to cross-validate the data and to capture different dimensions of male sexual victimisation. However, there are some important limitations to using semi-structured interviews and qualitative questionnaires. For example, the semi-structured interview method is inherently limited in the type of information that can be generated; for instance, it only gathers data in respect of what the interviewee tells the researcher about their social world (Bryman 2016). Thus, the interview data that were collected only contain information that the respondents chose to impart. With regards to the qualitative questionnaires, the response rate of questionnaires can be low (Edwards et al. 2002), which is why I disseminated the questionnaires to many police forces and voluntary agencies in order to increase the sample size and subsequently the chances of getting a high response rate.

4.6 Qualitative research places emphasis on social constructionism, meaning that qualitative researchers attempt to understand their participants' lived reality, which is socially, historically and culturally constructed (Bryman 2016). Thus, inductive theory was drawn upon for this work, in which theory emerge from the data, rather than taking a deductive approach, wherein a hypothesis is developed founded on current theories and then aiming to test such a hypothesis through a research strategy. Adopting an inductive approach was appropriate because I was dedicated to critically exploring the data without the limitations imposed by needing to test theory. This meant that data were examined before thinking about its connection to current knowledge in the subject matter of male sexual victimisation.

4.7 I drew on thematic analysis to analyze the data. Thematic analysis requires the researcher to recognise themes or patterns appearing out of qualitative data (Braun and Clark 2006). There was a concern to recognise differences and commonalities in the views and experiences of the participants. The researcher followed thematic analysis with thematic coding where codes/labels were placed onto segments of the data that looked important. Each transcript was read and reread by the researcher while noting down some initial codes and labels on the transcripts before transcripts were imported into the data analysis software NVIVO 10 for final coding. A stage of coding involved the analysis of sentences and words for common themes, concepts, and patterns across the data set. Analysing the data focused around organising the dissimilar concepts, conceptions and themes that developed from the data, not just on putting masses of data into order. Exploring hegemonic 
masculinity and the gender expectations of men were important to give a more nuanced and detailed account of certain themes in the data, which helped to make sense of how my participants' attitudes and responses get shaped. Understanding their attitudes, assumptions, ideas and meanings that underpinned their responses to male rape was key. For example, I understand and explain my participants' stories in relation to gender stereotypes and norms, connecting their descriptions to hegemonic masculinity. By doing so, I was also able to understand what roles gender, sexualities and masculinities play in the discourse of male sexual victimisation, achieving the core aims of this paper. Certain themes emerged in relation to male rape myths. For example:

- 'Men Cannot be Raped': Male Rape Challenging Men's Masculinity;

- "'Real' Men can Defend Themselves"; and

- 'Women Cannot Rape or Sexually Assault Men'.

4.8 The research participants are diverse in regards to amount of experience handling male rape cases, educational level, ethnic background and training of rape cases. The type of participants include the following: specialist police officers (4); police detectives (4); police constables (34); police sergeants (9); police response officers (2); male rape counsellors (7); male rape therapists (3); and voluntary agency caseworkers (7). The gender of the participants comprises of 33 males and 37 females. The sample is predominately white and most of the participants are under 40 years of age and are mostly from highly educated and middle-class backgrounds. The respondents provide services for many male rape victims, although they often serve more female rape victims due to the higher number of female rape victims who come forward. On average, the respondents have had around 7 years of experience of working with male rape victims and male victims of sexual assault; most of their clients are middle-class men. Some of my participants had no training on male rape and sexual assault against men, but most had training on female rape and sexual assault against women. To ethically carry out this work, I draw on reflexivity to highlight the many difficult issues that I had to deal with throughout the process of this study.

\section{Sociology of Male Rape Victim Reflexivity}

5.1 Undertaking this work on male rape has affected me in a number of different ways; most notably it has allowed me to reflect on my own experience of rape. As Davies (2012: 747) also experiences, I too experience this: "Writing academically and emotionally about my own emotional sensibilities and feelings [is] challenging", but we can "offer some academic analysis arising out of it". My sense of self is ultimately embedded in this research project because of my biography, history, experiences and victimisations. According to Foucault (1976), the products of social research reflect its social researcher, instead of representing some world that is independent of it. In parallel, Hammersley and Atkinson (2007: 14-16) argue that:

\footnotetext{
[S]ocial researchers are part of the social world they study...The concept of reflexivity acknowledges that the orientations of researchers will be shaped by their socio-historical locations, including the values and interests that these locations confer upon them. What this represents is a rejection of the idea that social research is, or can be, carried out in some autonomous realm that is insulated from the wider society and from the biography of the researcher, in such a way that its findings can be unaffected by social processes and personal characteristics...there is no way in which we can escape the social world in order to study it.
}

5.2 I agree with this argument. This is because I chose my research project due to my sexual victimisation and my subscription to homosexuality - in contrast to heterosexuality, heteronormativity and hegemonic masculinity - which often positioned me as subordinate, so I wanted to learn more about my suffering. Through the research project, I became equipped with the tools to make sense of my history, biography and sexual victimisation. At the same time, I also became able to understand and explain the ways in which my marginalisation, subordination, subjugation and alienation come about. Becoming reflexive, however, led me to question my objectivity and neutrality in this qualitative research. I wondered whether qualitative researchers could ever completely, objectively, or neutrally divorce themselves from the subject matter that they are researching. Edwards and Holland (2013: 84) similarly review that, "By virtue of being human, researchers are not neutral and objective enquirers in qualitative interviews but are emotionally engaged participants who are sharing an experience with the interviewee". Burawoy (2003) supports this, arguing that we cannot understand or study the external world without having a relationship with it.

5.3 My relationship with the external world that I had been researching stems from my very own experience of rape. As some of the participants asked me why I had chosen to study this area of topic, I had to be honest not only to them, but also to myself about why I had chosen this study of area, despite not wanting to talk about me as it created some angst. My participants appreciated my honesty, though, about choosing this research area 
because of my own sexual victimisation. I had to then make a decision on the spur of the moment about how much to disclose, even though researchers disclosing personal details to their participants is frequently seen as good research practice with some feminist writers supporting researchers' self-disclosure (e.g., Oakley 1981; Stanley and Wise 1983; Reinharz 1992). Disclosing my sexual abuse in this way lessened the hierarchical nature of the research process, in that it helped to break any barriers there may have been between the researcher and the participants in the interviews since the participants were more revealing after I disclosed my sexual victimisation. This, as a result, helped to encourage valid, detailed and in-depth responses from the participants, whilst helping to rapidly develop rapport between the participants and I, in order to build a research relationship that would easily allow me to access my participants' stories. The participants disclosing such detailed responses, however, triggered some flashbacks of my own suffering.

\section{Although I did not get any social support for my sexual victimisation during the duration of the research} process, emotional changes, sleeping disturbances and feelings of sadness, helplessness and frustration fluctuated within that time frame. As a result, so many times I wanted to abandon researching and writing about male rape, especially when it was becoming an emotionally difficult process, delving into the past and reliving some of my darkest moments. In a similar vein, Gailey and Prohaska (2011) found it emotionally challenging to interview men about sexually degrading behaviors, whereby men sexually objectify and degrade women through misogynistic sexual practices. After some of their interviews with the men, these women researchers became tearful and emotional.

It is the qualitative researcher's job to delve into other people's lives, sometimes at a time of hardship, stress and crises, and to ask them to talk in depth and detail about their views and experiences (Morse and Field 1995). Entering into the lives of my participants to understand male rape from their point of view was, to some extent, a process of secondary victimisation, in that I was made to relive some of my past experiences of abuse. This process was also a way of getting fine-grained, detailed, rich answers, which I needed to not only validate my own experience of sexual violence, but also to explore common themes that I could relate back to the literature on male rape to help understand this phenomenon. Therefore, to do this, understanding my participants' views was crucial. An interactionist approach is important, thereby, to help capture my participants' stories. Employing a qualitative approach was appropriate for achieving my aims. As I revealed my sexual victimisation to some of the participants due to being asked why I chose to study male rape, I was quite surprised at the depth of information offered to me by them. I felt a little uneasy about the level of disclosure that occurred in some research interviews since it was like they were centring their discussion on my experience or somehow relating it back to my personal experience. This felt like secondary victimisation.

5.6 In fact, the whole research process, from the inception of laying out ideas for the research to the writing up of this paper, was a form of secondary victimisation because I was continually reminded, re-living, and reflecting on my historical memories of abuse. Despite this form of insidious secondary victimisation, I was expected by some to "man up". Hammersley and Atkinson (2007: 82) establish that the researcher is "faced with the difficult task of rapidly acquiring the ability to act competently, which is not always easy even within familiar settings". Although I was situated in "familiar settings", such as fieldwork, workplace, sitting behind a laptop in my bedroom, I was struggling to embody hegemonic masculinity that was expected from me-strength, independence, unemotional, insensitive and control-which was difficult to do because of my feeling hierarchically marginalised and subordinate to other men who embody hegemonic masculinity. Given my compliance to homosexuality, being an ethnic minority, and identity as a victim of rape, robust barriers were inevitably raised that were difficult, if not impossible, to tackle. Ultimately, these barriers prevented me from enacting hegemonic masculine practices.

5.7 Suffering depression and post-traumatic stress disorder, as a result, made it emotionally challenging and difficult to carry out the fieldwork. This emotional upset was exacerbated when witnessing different sides and shades to my participants. For instance, by voluntarily helping out with activities relating to my participants organisations, such as making coffee, giving feedback on relevant books they are using for their clients, despite this process becoming very time consuming, I encountered sides of my participants that did not surface at the interviews. The ethical dilemma was whether to include this type of information into the paper, but I chose not to do so in order to ethically carry out this research. The 'off the record' type of information that I encountered were negative regarding the concept of male rape, but I only recorded what my participants wanted me to record and to use for my research. 
darkest moments in my life. Becoming insular, closed-off and insecure, even becoming emotionally upset and crying after some difficult interviews, my experience of studying male sexual victimisation shows the nature and extent to which other researchers studying sensitive topics are vulnerable and susceptible to further abuse. This feeling of embodying an 'outsider' is shared with many other scholars (e.g., Abdullah-Khan 2008; Davies 2012; Gailey and Prohaska 2011). I attempted to manage my own emotions, however, while I was at the 'front stage' (Goffman 1959) in front of people who cultivated or directed my research, such as my research participants, compared to when I was 'back stage' (ibid.) at home alone in my bedroom where I would emotionally fall apart and critically reflect.

\section{Masculinities, Gender Expectations, and Male Rape}

\section{'Men Cannot be Raped': Male Rape Challenging Men's Masculinity}

6.1 With Connell's theoretical framework in mind, male rape victims are often placed at the bottom of the gender hierarchy (Lees 1997; Weiss 2010; Turchik and Edwards 2012; Javaid 2014a, 2015a, b; Ferrales et al. 2016). Male rape victims embody a subordinate form of masculinity; they are oppressed, relegated and made subordinate for not achieving hegemonic masculinity. In other words, men are not expected to be a victim or a rape victim. Men, in particular, have been shown to be more likely to perpetuate this expectation and myth compared to women (Chapleau et al. 2008). This idea that male rape inverts, negates and undermines men's masculinity can be seen in the following quotes:

\footnotetext{
[l]t's still the issues I think about... how males perceive their masculinity as being affected by male rape. That's not something to actually happen to men...they may question themselves about their masculinity...as a man, you don't expect to be attacked like that (Specialist Police Officer 3, Female).

I think it [male rape] links to hegemonic masculinity. This idea that they [male rape victims] might be seen as less of a man (Police Detective 1, Female).

[T]here is an expectation in our society for men to be masculine and have more aggression than women so to speak. This could be where they might struggle, coming to terms with the expectations of their friends and family and of society with what they should do in that situation [male rape], in comparison to what is expected of women (Police Constable 11, Female).

Because you're a man, you are expected to 'man up'...The police would expect a man to be a 'man' and to be masculine and dominant (Voluntary Agency Caseworker 3, Male).

\begin{abstract}
They [men] are threatened by another type of masculinity or a masculinity that they don't understand, and I think it's linked to penetration as well...in general in culture and sex, women are seen to be penetrated. So if a man is penetrated, whether that is consensual or not, it makes him almost seem like a woman. It's difficult for men to understand, it's almost an inbuilt misogyny (Male Rape Therapist 2, Male).
\end{abstract}

These excerpts raise the issue of gender expectations of men and the configurations or representations of masculinity that men are expected to embody, including male rape victims. They are represented and expected to act as strong, powerful, tough, dominant, and in control. These quotes strongly suggest that male rape questions the ability of these men to practice hegemonic configurations of masculinity and thereby challenges their sense of self as what it means to be a 'man' and other research supports this finding (seeGroth and Burgess 1980; Gregory and Lees 1999; Chapleau et al. 2008). That state and voluntary agencies believe that men are not expected to be rape victims could potentially generate insensitive treatment, responses, and attitudes for deviating from gender norms and expectations. Male rape challenging male rape victims' masculinity has several implications. For example, they may withdraw from society, they may be reluctant to engage with the criminal justice system, or they may struggle to come to terms with their subordinate masculinity, as hegemonic masculinity is difficult for them to embody having been a victim of a crime that is seen solely to affect the female population.

6.3 Male rape victims can, however, "adopt hegemonic masculinity when it is desirable; but the same men can distance themselves strategically from hegemonic masculinity at other moments" (Connell and Messerschmidt 2005: 841). This suggests that male rape victims may be able to draw on hegemonic configurations of practice as well as being positioned at other times in subordinated configurations, depending on social structures, social contexts and social practices. In the context of male rape, it could be argued that male rape victims suffer a 'crisis of masculinity' for not being powerful, strong, and invulnerable, and, therefore, being positioned as unmasculine after their masculinity is 'stripped' away. When I say 'crisis', I mean that male rape victims' masculinity becomes questionable and contested. There is a form of 'existential angst' experienced when what they thought was a certain or secure identity becomes unstable, which may induce their subordinate 
masculinity, feminisation and lack of power. Allen (2002) argues that male rape is violent and masculine behavior, challenging and undermining of men's (male, gendered) identity. She says:

That men understand their experiences of, and responses to, rape in relation to 'being a man' is not surprising, since much of the feminist literature on female victims of rape has highlighted the importance of understanding the experience of women in a gendered context (p. 26-27)... while both men and women describe how sexual victimisation undermines their sense of 'autonomy', for men this acts as a direct challenge to the control they exert in the social and sexual arena, and therefore to their identity as men (p. 36).

6.4 Allen found that gender is important to understanding male rape, which, as well as the physical aspects, is seen as 'abnormal' and 'deviant', an attack against men's masculinity and men's sense of self, leaving them feeling a diminished sense of autonomy. In turn, men's feeling of isolation may be exacerbated, with each man feeling like he is the only one suffering what might be termed a 'masculinity crisis' in the context of male rape. Allen further argues that, in Western society, men are expected to have power and control and to always fight back against other men; by not achieving this expectation, men's masculine identity and worth are further questioned. She quotes a male rape victim who felt as if he failed as a man:

\footnotetext{
... during the rape I did have a very strong sense of what a 'man' should do in this situation. I don't know where this comes from. It must start in the family, then I suppose it's reinforced in the workplace and through friends...but, I certainly knew what was 'expected' of me (p. 43).
}

6.5 This indicates that the gender expectations of men are strongly embedded in Western culture. Connell (2005) and Connell and Messerschmidt (2005) support this, arguing that patriarchy still remains, whereby 'real' men exercise power, control, stoicism, insensitivity, and domination through social and gender relations, and social practices. My data suggests that men are expected to be unemotional, masculine, stoic, powerful, strong, aggressive and invulnerable, and certainly not expected to be a victim of rape. Male rape, however, clearly threatens the social norm of masculinity, as my own findings and Allen's (2002) suggest. As a result, the state and third sectors may perpetuate negative judgments against those men who have failed as 'men'. By men not enacting hegemonic masculinity configurations and becoming rape victims, they are feminised, as Male Rape Therapist 2 (Male) commented: "if a man is penetrated... it makes him almost seem like a woman." It could be argued that male rape victims who are emasculated and feminised may draw in negative views, attitudes and responses, may be negatively sanctioned, and made 'abnormal' by other men, including men working in state and voluntary agencies. For example:

\begin{abstract}
Men judge each other and encourage compliance by rewarding those who match the said criteria while censuring those who do not. Differences among individual men such as age, physical size and strength, class, wealth, sexual activity and so on are ranked according to the masculine stereotype and invested with varying degrees of patriarchal power; the characteristics become markers of masculinity or the lack of it (Allen 2002: 47).
\end{abstract}

6.6 It could be problematic if men (also women since, relationally, women can also enact hegemonic social practices and patterns of behavior (Connell and Messerschmidt 2005)) working in state and voluntary agencies position male rape victims' in subordinate masculinities because service delivery may then be denied or inadequate. Consequently, this could make male rape even more of a 'hidden' phenomenon (Abdullah-Khan 2008; Javaid 2014a) and foster classifying male rape victims as 'undeserving' victims because of their being positioned (much of the time) in configurations of practice other than hegemonic ones, which are divergent to the dominant and leading hegemonic masculinity in the hierarchy of masculinities. It is apparent that hegemonic masculinity is embedded in state and voluntary organisations as, "At the local level, hegemonic patterns of masculinity are embedded in specific social environments, such as formal organizations" (Connell and Messerschmidt 2005: 839). This suggests that power flows through state and voluntary organisations, meaning that they may unconsciously label male rape victims as 'undeserving' or as not 'real' victims, not worthy of protection and adequate treatment. Though men are more likely to be victims of interpersonal violence (Richardson and May 1999), the notion of 'undeserving' or not 'real' rape victims prevails because male rape victims (unconsciously) undermine and disrupt the power and authority of the gender order. This notion of 'undeserving' or not 'real' rape victims is echoed in the following quotes:

If you think about the idea of the deserving and undeserving victims, I think that [male rape victims] are almost attributed by the state as this undeserving victim label, so it is much harder for those victims to be heard and to have their complaint be deemed as a credible complaint... Why do we always begin with a stamp like that with these victims who shouldn't be believed, because it turns the whole criminal justice system on its head...But this idea that, if you're an undeserving victim, then it takes so much more for someone to believe you. I think that male rape is one of those areas that is really hard for people to understand...so people might be more inclined to think it's made up (Police Detective 1, Female). 
I think it's the fear and the machismo..."that would never happen to me" kind of thing in our culture, you don't really discuss it [male rape] in a real way (Male Rape Therapist 3, Male).

These passages suggest that male rape victims are compartmentalised as 'undeserving' of victims status or, similarly, are conceptualised as not 'real' rape victims because they are men. Richardson and May (1999) demonstrate that violence, such as sexual violence, is socially constructed and defined differently amongst people. How people come to define and construct violence, or sexual violence, is largely shaped by interactional and social contexts wherein it is framed and by social traits of the victim (Richardson and May 1999). Unconsciously classifying male rape victims as 'undeserving' of victim status and as not 'real' victims, based on how rape is socially constructed, is problematic. This is because these victims are, as a result, highly likely to be disbelieved (Lees 1997), seen as not credible complainants (Walker et al. 2005), and the male rape myths that "male rape does not exist" or "men cannot be raped" may very well be perpetuated across societies, state agencies (Chapleau et al. 2008; Abdullah-Khan 2008) and voluntary service provisions (Cohen 2014; Javaid 2016a, b). Richardson and May (1999: 309) say that "some individuals are seen as...less deserving of victim status than are others on the basis of their 'behavioural responsibility' for risk avoidance...gender of the victim is significant in terms of expectations of 'behavioural responsibility' for avoiding social contexts... associated with... violence."

\title{
"'Real' Men can Defend Themselves"
}

It is fair to say that men are expected, as my data suggests, to avoid potential threats or actual occurrences of rape. By not avoiding rape, they are expected to fight off their attacker(s) to demonstrate hegemonic masculinity not only to themselves, but also to other men, including their attacker(s). Warding off rape in this way, arguably, enables these men to enhance their masculinity and to prevent disbelieving, hostile and homophobic attitudes and responses from societies and from state and voluntary agencies. Linked to this notion of 'fighting back', my data shows the following:

[There is a] perception that the guy is weak or submissive and unlikely to fight back....Sometimes [male rape victims] never fight back because of fear of repercussions and because they are likely to be physically or mentally weaker than the perpetrator of the act (Voluntary Agency Caseworker 2, Male).

I think the male victim's struggle in their minds that they were not able to fight off their attacker...Depending on the circumstances of the rape may well cast aspersions as to the stereotypical ideas that male rape covers i.e., "Why didn't they fight them off?" (Police Constable 4, Female).

\begin{abstract}
A lot of the males I have worked with have...been asked why they didn't fight back (expectation that men are strong) and categorically been told "you must have got it wrong, men can't get raped". While female victims also come up against societal view, the impact seems to be greater for men. Male victims can also (not always) struggle with the emotional fallout from sexual assault. There is a pressure that many report feeling from those around them that they should be strong (not show emotion) and not talk about it because the assault makes them look weak (Male Rape Counsellor 7, Female).
\end{abstract}

[T]here is an expectation in our society for men to be masculine and have more aggression than women so to speak. This could be where they might struggle, coming to terms with the expectations of their friends and family and of society with what they should do in that [rape] situation, in comparison to what is expected of women...if they [rapists] find someone completely sober with their wits about them, if they're not under fear or duress, they have a way of fighting back (Police Constable 11, Female).

They [male rape victims] think that they will be looked upon as being weak and "why didn't they fight their attacker." They think they will be judged and also they do not want it being made public nor others to know due to negative comments and behaviour towards them. They may not also want the police to get involved (Police Constable 25, Female).

6.9 These excerpts indicate that the male rape myths that "'real" men can defend themselves against rape' or 'men are expected to always fight back' are present not only in societies, but also in the state and third sectors that serve male rape victims. Groth and Burgess (1980) and Chapleau et al. (2008) support this finding, arguing that men are always expected to protect themselves if/when threatened with rape. Chapleau et al. go on to argue that '[people] will judge male rape victims harshly for not being "man enough" to escape a sexual assault and, if assaulted, expect male victims to quickly reclaim their manhood and deny that the assault was traumatic' (p. 604605). Turchik and Edwards (2012) argue that these male rape myths render, in part, male rape to be unchallenged, untackled and render male rape victims to be uncared for. Toxic and harmful gender expectations of men and preconceptions, such as "victims of rape should fight back" and "they are likely to be physically or mentally weaker than the perpetrator of the act" (see findings above), can provide a disservice to male rape victims, perpetuating patriarchy and reinforcing gender norms and ideals. Because male rape myths, such as 
these, dominate the state and third sectors, male rape victims are actively unacknowledged, invisibilised, alienated and marginalised (Turchik and Edwards 2012). Holding onto these male rape myths, which may induce victim-blaming attitudes (Walker et al. 2005; Chapleau et al. 2008; Rumney 2009) or homophobia (Kassing et al. 2005), ignores that many male rape victims are unable to fight off their offender(s) at the time of their rape because of fear, intimidation, and control. For instance, in Gregory and Lees' (1999: 116) research, while finding that "male complainants were particularly anxious if they had not resisted, which they feared would lead people to assume they had colluded", they also found that many male rape victims cannot fight off their attacker(s) because "[t]he threat of violence [is] usually sufficient to gain compliance" (ibid.: 121).

6.10 If male rape victims do not fight back, there is a risk that they may be seen as partaking in consensual sex, having "wanted it", and/or having failed in their duty as 'men'. In other words, they may be seen as weak, powerless, pathological, and not 'real' men, as my findings suggest. In addition, some authors add that a feminine identity is enforced onto male rape victims (e.g., Turchik and Edwards 2012; Ferrales et al. 2016) for not demonstrating hegemonic masculinity during their rape. In this context, there is an expectation for male rape victims to achieve hegemonic masculinity, enacting physical resistance, aggression, strength, courage, bravery, power and dominance, by fighting off their sexual offender. Submitting to their rape and complying with their attacker(s), however, are inconsistent to the heterosexual masculine ideal. Despite this, men can reclaim back their hegemonic masculinity by fighting back (Messerschmidt 2000), such as against their sexual offender(s), which may prevent subsequent negative attitudes, responses and sanctions directed toward male rape victims. By doing so, these victims can show not only to themselves, but also to other people and to other men that they are 'man enough' to deal with situations by themselves without any help or support since a 'real' man is obligated to respond in this way (ibid.). Carrying out self-reliance, independence, strength, power, violence, and aggression may, therefore, allow male rape victims to reclaim back their hegemonic masculinity while preventing stigma and derogatory labels, such as "queers", "wimps" or "pussies".

6.11 From my data, there was also a belief that men "may be physically similar" (Police Constable 23, Male). This view could be problematic because all males come in many different sizes, shapes, and weights, so this biological deterministic view may attempt to generalise all males/men as being similar and as a fixed inherent category, which challenges Connell's (2005) view that men are a social category. It is safe to argue that the male rape myth "men are expected to fight off their rapist" may be prevalent in state and voluntary agencies but is pernicious to male rape victims' lives. Thus, because "male rape myths are embedded within our language, across all institutions, the words chosen to describe rape victims...such as [using] feminine pronouns, can have a negative impact on male victims and contribute to the promotion of rape myths" (Turchik and Edwards, 2012: 221). While sexism and male rape myth acceptance may be high in state and voluntary agencies and in societies, men rather than women are more likely to be sexist and to subscribe to male rape myths (Chapleau et al. 2008), including male police officers and male practitioners working in the third sector. Therefore, it appears that men may convey sexist attitudes toward other men who are deemed an anomaly for deviating from gender norms and ideals.

\section{'Women Cannot Rape or Sexually Assault Men'}

6.12 Another finding that emerged from the data is the issue of women raping men. Although women cannot be prosecuted for rape in English law, my data suggests that it is a prevalent phenomenon. Some of my participants, however, held the view that "women cannot rape men". This male rape myth, arguably, is deleterious because it may render men who have been sexually assaulted or raped by women seem unworthy of a victim status, which in turn may shape the type of service and response they receive. The following quotes shed light on this particular male rape myth, and the issue of women raping men is highlighted in the below quotes:

I...know a lot more about women as abusers and how frequent that is, so women do rape men. That's another side of it [male rape] that I have seen. It definitely has opened my eyes since working here... We see it [women raping men] a lot in childhood sexual abuse. The figures are older women who are of an authority, abusing young men. We also see it in young relationships...we see attacks on young men [by women]. The only difference is [that] it's not classed as rape. We class it as rape, but, in the law, it's not classed as rape... we see that [women raping men cases] quite a lot l'd say. $20 \%$ of our survivors are men, and l'd say $10-15 \%$ of them have been attacked by women, which is quite high. That's probably the main thing that l've learned since being here, that women are abusers and it is a lot more prevalent than you would imagine (Male Rape Counsellor 3, Female).

That [women cannot be prosecuted for rape] needs to be changed because I think there is plenty of domineering women. God, you just have to look at the lesbians on the scene [laughs]. There are lots of guys who are terrified of their wives...Whereas a woman forces herself onto a man, he'll struggle to have that taken seriously.... a police officer 
going behind the scenes and going, "oh, we've got a right one here. He reckons his wife's raped him". That kind of attitude, and I think it will take some convincing from his point of view. In society, men are expected to have sex with women. They are supposed to have sex with their wives, so when he goes to the police and reports, and to say that well, "she's raped me", implying that he didn't want to have sex with her, then that challenges masculinity...when the wife has raped the guy or abusing the guy...he's expected to be the dominator...I think the straight male, the ordinary joe in the pub sort of thing, reading about a situation where a wife has raped her husband, he would be the focus of a huge joke...they would go, 'arghhh you wanted it anyway man' (Voluntary Agency Caseworker 3, Male).

\begin{abstract}
I'm probably more aware of it [women raping men] if I'm honest. I'm more aware of sexual violence in culture and how it's portrayed in the media and all the rest. Like how it can be with an older woman and a younger man, how many think "oh well she was just initiating it" but actually it was rape. And that's one area that's not really discussed, in that misogynistic framework of how women are considered capable of rape. I remember seeing a film "40 days and 40 nights", a rom-com, and a scene where a woman has handcuffed a man to a bed and is basically forcing him to have sex with her. It was done in a funny way, but I thought, "flippin' heck! That's rape" (Male Rape Therapist 3, Male).
\end{abstract}

6.13 These quotes demonstrate the prevalence of women raping men. Based on these narratives, what strikes me is the view that men are intrinsically in need of sex with women, suggesting that women are responsible to fulfill their needs. Defining rape, therefore, becomes problematic. When women do rape men, men are expected to 'man up', to deal with it, or otherwise may be seen as having secretly enjoyed their rape. It appears that rape is still thought of as non-consensual vaginal-penile penetration; by women not having a penis, they are seemingly unable to rape. Despite the belief that men have a biological urge or need for sex, and despite that they are supposed to initiate sex with women and enjoy it, pornography particularly conveys this notion, many men simply do not enjoy forced sex by women. This biological positivistic ideology is empirically flawed. I argue that the sociological constructionist ideology is more appropriate to understanding male sexual victimisation.

6.14 Having said that, the above quotes link to the concept of hegemonic masculinity and social constructions of masculinities. For example, both Connell (2005) and Weiss (2010) argue that 'real' men are expected to be promiscuous and to have sex with women, and lots of women, in order to embody hegemonic masculinity and heterosexuality, demonstrating to themselves and to other men that they are 'real' men (in other words, they are not attracted to other men). Therefore, the gender expectations of men shape the view that men, including male rape victims, are supposed to dominate and initiate sexual intercourse with women, not be sexually victimised by them. The idea that men who have been raped by women goes against this gender ideal, which in turn may bring about backlash against male rape victims. As a result, men who have been raped or sexually abused by women may not be taken seriously and may have their sexual victimisation trivialised; they may be overlooked, secondary victimised, laughed at, or made a mockery of. These implications may not only occur in the state and third sector settings, but also in the wider societies for "men who admit that they do not want sex or, worse, were forced to have sex violate codes of male (hetero)sexuality" (Weiss 2010: 277). Weiss adds that, "The fact that men are victimized so often by women certainly contradicts cultural stereotypes about women as passive, both physically and sexually, as well as the assumption that men are exclusively the aggressors of sexual violence" (p. 284). In support of this, taken together, my findings debunk the male rape myth that 'only men rape other men'.

6.15 Relatedly, the findings also point out to the concept that women can also embody hegemonic masculinity in a given setting, context, and situation, which concurs with Connell (2005) and Connell and Messerschmidts' (2005) sociological framework, that hegemonic masculinity is relational, interactional, socially constructed, and an enactment of violence, power and dominance. I would argue, however, that though both women and men can embody hegemonic masculinity, men are more likely to draw on it. Weiss (2010) and Ferrales et al. (2016) support my finding regarding women sexually victimising men. Weiss found that the gender expectations of men and gender ideals conceal the possibility that women can be sexual aggressors in societies because "social constructs of femininity... as physically weak and sexually vulnerable...fit overall perceptions of sexual victims" ( $p$. 277). As my findings suggest, however, men are not socially constructed as "physically weak and sexually vulnerable", which means that they may be illegible to be seen as rape victims. If state and voluntary agencies hold the view that women cannot rape or sexually assault men-e.g., "...a woman can't rape a man" (Police Constable 3, Male) - they may disbelieve, neglect or inadequately deal with men who have been raped or sexually abused by women. Expressing victim-blaming attitudes, in turn, to these victims is problematic because it can serve to invalidate their experience of rape. At the same time, as Connell (2005) and Carlson (2008) argue, those men not fulfilling the criteria of hegemonic masculinity and becoming victims draw in demeaning, humiliating and disparaging language, such as being called "faggots", "puffs", or "queers". 
6.16 From my data, it appears that such derogatory language may be perpetuated in police forces. For instance, Voluntary Agency Caseworker 3 (Male) says that "a police officer going behind the scenes and going, 'oh, we've got a right one here. He reckons his wife's raped him'. That kind of attitude... behind people's backs, people are still slagging people off". This narrative suggests that derogatory language may be expressed in police forces, although it may not directly and explicitly be expressed to male rape victims. Therefore, this "behind the scenes" language may take place 'backstage'. Goffman (1959) developed a dramaturgical model, in which he demonstrated that, utilising particular methods, individuals (actors) showcase themselves to display a social performance that is appropriate in a given context. He calls this impression management. In this model, he developed 'front stage and back stage'. Within the former, groups of people or individuals (such as police officers) socially perform in front of an audience (such as complainants). It is here where, as Goffman says, performers can hide their true beliefs, thoughts and views until they can uncover them in the backstage. In the backstage, then, the performers can break rules and regulations and reveal negative thoughts, beliefs and views should they choose to. Goffman's theoretical perspective is important because it suggests that police officers may not directly express derogatory language to male rape victims, face-to-face, but may nonetheless unleash such language in the informal backstage to their colleagues, making a joke and mockery about male rape, laughing about it, demeaning and degrading the victims 'behind their back' or 'behind closed doors'.

6.17 More recent research concurs with Goffman. For example, Pascoe and Hollander (2016: 69) argue that men can, in order to 'do' gender, engage in "nonconsensual sexual interaction, talking about rape and sexual assault, making jokes about it, laughing at imagery about it, labeling oneself or others as rapists, blaming sexual assault survivors for their own victimization, or...symbolically deploying the idea of rape". As an interactional accomplishment, they suggest, male police officers are 'doing' gender by collectively shaming, downgrading, and emasculating male rape victims to enhance their own gendered status as masculine and to celebrate their own dominance over 'inferior' men who are victims of rape. Thus, "practices, discourses, and symbols associated with sexual violence and assault may be deployed in the service of masculine dominance at interactional, discursive, structural, symbolic, and global levels" (ibid.). From the evidence supplied here, it seems that the police may trivialise male sexual victimisation (for example, symbolically and discursively), and so the police not taking it seriously may deem it as 'unimportant' and laughable. Consequently, because police officers position male rape victims as 'failed' men "by drawing on cultural resources that affirm expectations of normative masculinity" (ibid.: 68), male rape victims or male victims of sexual assault may be disinclined to engage with the police and the criminal justice system, preventing prosecution.

6.18 At the same time, police officers can also strengthen, perpetuate and enhance their hegemonic masculinity, manhood, and solidarity since police forces are, arguably, hyper-masculine environments. Because the police display power and support hegemonic masculinity, Messerschmidt (1993) argues that police forces are inherently hierarchical and violent institutions. He goes on to argue that hegemonic masculinity is socially constructed and institutionalised in police agencies, which suggests that other forms of masculinities, such as subordinate and gay masculinities, may be measured alongside hegemonic masculinity in police forces. In other words, male rape victims displaying subordinate masculinities may be judged harshly in police agencies. In police agencies, he adds, patriarchy is prevalent along with masculine characteristics, such as being tough, unemotional, insensitive, and detached whilst keeping away from social action or characteristics associated with womanliness or femininities. Similarly, Acker (2006) suggests that organisations, such as police forces, produce and reproduce gender inequality founded on power relations and "shaped by gendered and sexualized attitudes and assumptions" (p. 444). Furthermore, Acker stipulates that:

\footnotetext{
All organizations have inequality regimes, defined as loosely interrelated practices, processes, actions, and meanings that result in and maintain class, gender, and racial inequalities within particular organizations. The ubiquity of inequality is obvious...I define inequality in organizations as systematic disparities between participants in power and control (2006: 443).
}

6.19 Therefore, it may be safe to put forward that, if male rape victims and the subject of male rape symbolise and personify subordination, weakness and feminisation, male rape victims may be downgraded, relegated and made 'abnormal' in the gender hierarchy within police agencies since "[in] police agencies, men's power is deemed an authentic and acceptable part of social relations. This legitimacy of the power by men in police work adorns them with greater authority" (Messerschmidt 1993: 175). This suggest that the police are able to exercise power against male victims of rape, meaning that they can accept these victims as 'real' rape victims or, on the flip side, refute them of a victim label, which in turn may formulate negative, poor, and deleterious police attitudes and responses. Challenging police officers' hegemonic masculinity may bring about severe reactions, antagonism, and repudiation against male rape victims. My findings support Messerschmidt's theoretical perspective in that police forces are hyper-masculine environments and police officers exude hegemonic 
masculinity, which can be problematic. For example:

[F]or men, I think [it] must be harder to come forward to report that [male rape] to the police...looking at it from a male perspective, if you were to look at the police and "right, I'm going to report" and you look at the majority of officers are probably male, to then think about going and reporting that in a predominately male environment, must be quite a hurdle to get over initially...even if knowing that there's women who are gonna speak to you (Specialist Police Officer 3, Female).

I've worked with the police and they are very male men's men and a lot of them are very arrogant...a lot of them will be dismissive and a lot of them will think, 'oh, just man up'...voluntary agencies try to take [male rape victims] more seriously than the police initially do. [T]hinking about those kinds of [officers], they'll think that they [male rape victims] are 'always up to it'. [The police will] be skeptical lets just say that; they will need some initial convincing and I think that sometimes the victim will not be able to do the convincing...there will be a lot of judgment... [the police] dismiss it [male rape] as a lifestyle choice. When [officers] talk about the history and what things have happened to [victims], they will be very highly skeptical (Voluntary Agency Caseworker 3, Male).

Majority of the police are male.... and you have to understand the police culture, it is a powerful culture, and police officers are not likely [to] understand the acceptance of being a [male rape] victim... police officers recruit people that are like themselves. They tend to recruit their own "clones". They are indoctrinated into [a] system that reinforce[s] the prejudices and conscious bias (Voluntary Agency Caseworker 4, Male).

I suppose that police force is seen being maybe not as diverse as it should be, and probably isn't...and I suppose that police force is viewed as quite sort of White, male, probably straight, and that's probably intimidating and puts people off to come forward (Police Constable 3, Male).

6.20 These narratives suggest that hegemonic masculinity is present in police forces. For example, the police are seen as very macho, confrontational, arrogant, and in complete control, holding onto gender norms that encourage and support hegemonic masculinity. Despite there being women police officers, male rape victims and societies still view the police as patriarchal. As a result, these victims are unlikely to engage with police agencies for fear of being ridiculed, disbelieved and humiliated because they cannot measure up against police officers' hegemonic masculinity. As my findings point out, the police are likely to think that male rape victims need to "man up" or they are "always up to it", meaning that they are sexually promiscuous and so male rape is not really 'rape' in the eyes of the police; it is just another form of casual sex. Blachford (2002) comments that men doing casual sex are profoundly frowned upon, inviting condemnation, disapproval and stigmatisation. In addition, because of the hegemonic masculine police culture, male rape victims are expected to "get over it". On balance, police skepticism, which is a core part of police occupational culture (Reiner 2010), is increased and outwardly projected onto male victims of rape and male sexual assault victims. As a result, male rape "is not taken as seriously as rape suffered by women" (Voluntary Agency Caseworker 7, Male).

\section{Discussion}

7.1 Three salient themes emerged in the data. First, 'Men Cannot be Raped': Male Rape Challenging Men's Masculinity. Second, "'Real' Men can Defend Themselves". Third, 'Women Cannot Rape or Sexually Assault Men'.

Regarding the first theme, through exploring what role gender and masculinities play in the discourse of male sexual victimisation through the respondents' perspectives, it was found that male rape challenges and affects men's masculinity, hindering them from embodying hegemonic masculinity. This finding is in agreement with other research (see Groth and Burgess 1980; Lees 1997; Allen 2002; Abdullah-Khan 2008; Javaid 2014a, 2015a). Men are often unable to defend themselves during their rape, which challenges hegemonic masculinity, because, like female rape victims, men are frozen with fear or with the threat of death. Men's socialisation can explain the gender difference in that gender stereotypical views shape people's view of how men should respond to the threat of rape, that is, by always fighting back. The reality, of course, is that some men cannot fight back, especially if they are intoxicated or high on drugs. Male rape victims inverting hegemonic masculinity in this way may draw in repulsion, antagonism, and hostility.

7.3 Regarding the second theme, a high proportion of respondents subscribed to the male rape myth that 'male rape is solely a homosexual issue'. In societies, this myth is prevalent, whereby male rape is mistakenly seen to only affect non-'real' men; that is, gay or bisexual men. This finding concurs with current literature on male rape (see Abdullah-Khan 2008). The theoretical framework of hegemonic masculinity proved useful, in that it shed light on the fact that male rape victims embody or are seen to enact subordinate masculinities. As a result, they are relegated or downgraded to the bottom of the gender hierarchy, which in turn increases their risk of suffering homophobic reactions, attitudes, responses or appraisals from others, notably from other men since the 
act of male rape challenges both hegemonic masculinity and heternormativity.

The final theme that emerged relates to the myth that 'women cannot rape or sexually assault men'. This theme certainly challenges and confronts radical feminist theoretical ideology, where rape is only seen to apply to women (see radical feminists MacKinnon 1989; Temkin 1982, 1987; Naffine 1992). Radical feminist Brownmiller (1975) defined the 'criminal act of rape' as an incident wherein "a woman chooses not to have intercourse with a specific man and the man chooses to proceed against her will" (p. 18), suggesting that men cannot be raped, or that women cannot rape or sexually assault men. Subscribing to this rape myth, arguably, is problematic because state and voluntary agencies may disregard, overlook, or poorly deal with male victims who have been sexually abused by women. This harmful myth may foster negative attitudes and responses to these types of male victims. However, feminists still see rape as a method of domination and control only against women, a "conscious process of intimidation by which all men keep all women in a state of fear" Brownmiller 1975: 15. Italics added). Feminist research is founded on the idea that rape victims are always female and the sexual offenders are always male. This mistaken view that the offenders are always male, I argue, is incorrect. Both Graham (2006) and Cohen (2014) argue, which I agree with, that it is understandable in a predominantly female sexually victimised society that feminist literature would focus purely on female victims because feminists do not see rape as gender-neutral, yet "focusing exclusively on female victimization is problematic" (Graham 2006: 187). The current study has shown that masculinity theorists are more accepting of men as victims of rape, than feminist theorists are.

The theoretical contribution of my data is that it sheds light on the interconnections between gender, sexualities and male rape, drawing on the theoretical framework of hegemonic masculinity. I have shown, which previously has been overlooked in the literature on male sexual victimisation, that male rape victims can move through different masculinities, either consciously or subconsciously, depending on social structures, social institutions, and social contexts. Some of these victims, though, are often positioned in subordinate masculinities because of the mistaken view that male rape is solely a homosexual issue. The male victims can embody hegemonic masculinity, but this is difficult to do, through the 'masculine' act of defending themselves (or 'putting up a fight') when threatened with rape. When being served by state and voluntary agencies, the male victims can also present themselves as unemotional and/or insensitive to enact masculine social practices. Revealing emotion and/or sensitivity, however, may place these victims in subordinate masculinities that may bring about disgust or disdain being directed towards them. The findings contradict Collier's (1998) and Hearn's (2004) view, then, that hegemonic masculinity is seen as a fixed entity; instead, the findings show that it is vulnerable to change and male rape victims can embody it at certain times, spaces and places, but, at other times, they can disengage from it when it is least desirable or productive. This support's Connell's (2005) theoretical arguments.

The limitation of my study is that I acquired a small sample size $(n=70)$, so the findings from the interviews and questionnaires cannot be generalised to the wider population, meaning that the sample may not necessarily represent the population of state and voluntary agencies that deal with male rape and sexual assault against men. Therefore, I encourage future research to gain larger sample sizes, so that the result can be generalized to the wider population, and to use both qualitative and quantitative methodologies and research methods to examine the nature and pattern of male sexual victimisation from a gender perspective. Furthermore, though the questionnaires provided somewhat limited data, I supplemented this with the interviews that generated more in-depth, rich and detailed answers. Further research, thus, may want to use more unstructured interviews to gain much more richer data with state and voluntary agencies or with male rape victims/offenders. Despite these limitations, the present study has increased the knowledge in the field of adult male sexual victimisation by gaining a better understanding of the different roles that gender and masculinities play in the discourse of male rape, and how they affect and shape state and voluntary agencies' understandings and views of men as victims of rape.

\section{Conclusion}

8.1 This paper has raised themes, concepts and conceptions relating to gender and masculinities. A recurring theme that emerged across the data, for example, was the issue of male sexual victimisation affecting and challenging men's masculinity, particularly their hegemonic masculinity. I found that societies, state and voluntary agencies expect men, including male rape victims, to be masculine, aggressive, strong, powerful, invulnerable, insensitive and unemotional. By male rape not being regarded as a serious issue in societies and in the state and third sectors, the issue of male rape is concealed, 'hidden' and deemed as 'unimportant', particularly because it challenges the status quo and the gender order of men. As the police expect a man to be a 'man' and to be masculine and dominant, notions of deserving and underserving victims come into play. In other words, male rape victims are labeled as undeserving of a victim status. As a result, public and police attitudes and 
perceptions, in general, are that 'men cannot be raped'. Another recurring theme that emerged in the data and discussed in this paper include the issue around fighting back. By not fighting off their attacker(s) during their rape, male rape victims may be seen as engaging in a consensual act because men are expected to be strong, self-reliant and to always be able to protect themselves. It appears that the state and third sectors hold this view of expecting male rape victims to fight back. Male rape victims, however, are unlikely to fight off their offender(s) because of fear, intimidation, and control. Linked to this finding, police are more likely to overlook or disbelieve a case in which a woman has raped a man because men are expected to initiate, have, and pursue sex with women. From the arguments made in this paper, it is clear that some police forces may consider male rape as unimportant and a joke, further propelling male rape to be hidden 'in the closet.'

\section{Notes}

$1 \quad$ 'Male rape' will be referred to as men raping other men for the purpose of this paper.

\section{References}

ABDULLAH-KHAN, N. (2008) Male Rape: The Emergence of a Social and Legal Issue Hampshire: Palgrave Macmillan.

ACKER, J. (2006) 'Inequality Regimes: Gender, Class, and Race in Organizations.'Gender and Society, 20(4): p. 441-464. [doi:10.1177/0891243206289499]

ADAMSON, J., Gooberman-Hill, R., Woolhead, G., and Donovan, J. (2004) "'Questerviews': using questionnaires in qualitative interviews as a method of integrating qualitative and quantitative health services research." Journal of Health Services Research \& Policy, 9(3): p. 139-45. [doi:10.1258/1355819041403268]

ALLEN, S. (2002) 'Male victims of rape: Responses to a perceived threat to masculinity.' InNew vision of crime victims (eds.). Hoyle, C. and Young, R. Oxford: Hart Publishing.

BADENOCH, K. (2015) Silent Suffering: Supporting the Male Survivors of Sexual Assault London.

BLACHFORD, G. (2002) 'Male Dominance and the Gay World'. In: K. Plummer (ed.)Sexualities: Critical Concepts in Sociology (Vol. 3). London and New York: Routledge, p. 295-320.

BRAUN, V., and Clarke, V. (2006) 'Using thematic analysis in psychology.'Qualitative Research in Psychology, 3(2): p. 77-101. [doi:10.1191/1478088706qp063oa]

BROWNMILLER, S. (1975) Against Our Will: Men, Women and Rape. London: Penguin.

BRYMAN, A. (2016) Social Research Methods. 5th edition. Oxford: Oxford University Press.

BURAWOY, M. (2003) 'Revisits: An Outline of a Theory of Reflexive Ethnography.'American Sociological Review, 68(5): p. 645-679. [doi:10.2307/1519757]

CARLSON, M. (2008) "I'd rather go along and be considered a man: masculinity and bystander intervention." Journal of Men's Studies, 16(1): p. 3-17. [doi:10.3149/jms.1601.3]

CARPENTER, S. (2009) The Psychological Effects of Male Rape. [Online] Retrieve at http://www.counsellingdirectory.org.uk/counselloradvice9907.html; accessed on 09/06/2014.

CHAPLEAU, K. M., Oswald, D. L., and Russell, B. L. (2008) 'Male Rape Myths: The Role of Gender, Violence, and Sexism.' Journal of Interpersonal Violence, 23(5): p. 600-615. [doi:10.1177/0886260507313529]

CLARK, J. N. (2014) 'A Crime of Identity: Rape and Its Neglected Victims.'Journal of Human Rights, 13(2): p. 146-169. [doi:10.1080/14754835.2014.886952]

COHEN, C. (2014) Male Rape is a Feminist Issue: Feminism, Governmentality, and Male Rape Hampshire: 
COLLIER, R. (1998) Masculinities, crime and criminology: Men, heterosexuality and the criminal(ised) other. London: Sage.

CONNELL, R. W. (1987) Gender and Power. Sydney: Allen and Unwin.

CONNELL, R.W. (1995) Masculinities. Cambridge, UK: Polity Press.

CONNELL, R. W. (2005) Masculinities (second edition). Berkeley: University of California Press.

CONNELL, R. W., and Messerschmidt, J. W. (2005) 'Hegemonic Masculinity: Rethinking the Concept.'Gender and Society, 19(6): p. 829-859. [doi:10.1177/0891243205278639]

DAVIES, P. (2012) "'Me', 'me', 'me': the use of the first person in academic writing and some reflections on subjective analyses of personal experiences". Sociology, 46(4): p. 744-752. [doi:10.1177/0038038512437897]

DONNELLY, D., and Kenyon, S. (1996) "'Honey we don't do men": Gender stereotypes and the provision of services to sexually assaulted males.' Journal of Interpersonal Violence, 11(3): p. 441-448. [doi:10.1177/088626096011003009]

EDWARDS, P., Roberts, I., Clarke, M., DiGuiseppi, C., Pratap, S., Wentz, R. (2002) 'Increasing response rates to postal questionnaires: systematic review.' BMJ: British Medical Journal 324: p. 1183-1185. [doi:10.1136/bmj.324.7347.1183]

EDWARDS, R., and Holland, J. (2013) What is Qualitative Interviewing? London: Bloomsbury.

FERRALES, G., Brehm, H. N., and Mcelrath, S. (2016) 'Gender-Based Violence Against Men and Boys in Darfur: The Gender-Genocide Nexus'. Gender and Society (advance online publication). [doi:10.1177/0891243216636331]

FOUCAULT, M. (1976) 'Truth and Power'. In Rabinow, P. (eds.) Essential Works of Foucault, Volume 3. New York: the Free Press, p. 111-33.

GAILEY, J. A., and Prohaska, A. (2011) 'Power and gender negotiations during interviews with men about sex and sexually degrading practices'. Qualitative Research, 11 (4): p. 365-380.

GOFFMAN, E. (1959) The presentation of self in everyday life. New York: Doubleday.

GRAHAM, R. (2006) 'Male rape and the careful construction of the male victim.'Social Legal Studies, 15 (2): p. 187-208. [doi:10.1177/0964663906063571]

GREGORY, S., and Lees, S. (1999) Investigating Sexual Assault. London: Sage.

GROTH, A. N., and Burgess, A. W. (1980) 'Male Rape: Offenders and Victims.'American Journal of Psychiatry, 137 (7): p. 806-810.

HAMMERSLEY, M., and Atkinson, P. (2007) Ethnography: Principles in Practice(3rd edn). London: Routledge.

HEARN, J. (2004) 'From Hegemonic Masculinity to the Hegemony of Men'.Feminist Theory, 5(1): p. 49-72. [doi:10.1177/1464700104040813]

HODGE, S., and Canter, D. (1998) 'Victims and Perpetrators of Male Sexual Assault.'Journal of Interpersonal Violence, 13 (2): p. 222-239.[doi:10.1177/088626098013002004]

JAMEL, J. (2010) 'Researching the Provision of Service to Rape Victims by Specially Trained Police Officers: The Influence of Gender-An Exploratory Study.' New Criminal Law Review: An International and Interdisciplinary Journal, 13 (4): p. 688-709.[doi:10.1525/nclr.2010.13.4.688]

JAMSHED, S. (2014) 'Qualitative research method-interviewing and observation.' Journal of Basic and Clinical Pharmacy, 5 (4): p. 87-88. [doi:10.4103/0976-0105.141942]

JAVAID, A. (2014a) "Feminism, Masculinity, and Male Rape: Bringing Male Rape 'out of the Closet."'Journal of Gender Studies, 25 (3): p. 283-293. 
JAVAID, A. (2014b) 'Male Rape in Law and the Courtroom.'Web Journal of Current Legal Issues, 20 (2).

JAVAID, A. (2015a) 'The Dark Side of Men: The Nature of Masculinity and its Uneasy Relationship with Male Rape'. The Journal of Men's Studies, 23 (3): p. 271-292.

JAVAID, A. (2015b) 'Male Rape Myths: Understanding and Explaining Social Attitudes Surrounding Male Rape.' Masculinities and Social Change, 4 (3): p. 270-294. [doi:10.17583/mcs.2015.1579]

JAVAID, A. (2015c) 'Police Responses to, and Attitudes Towards, Male Rape: Issues and Concerns'International Journal of Police Science and Management, 17 (2): p. 81-90.

JAVAID, A. (2015d) 'The Role of Alcohol in Intimate Partner Violence: Causal Behaviour or Excusing Behaviour?' British Journal of Community Justice, 13 (1): p. 75-92.

JAVAID, A. (2016a) "Voluntary Agencies' Responses to, and Attitudes toward Male Rape: Issues and Concerns". Sexuality \& Culture, 20 (3): p. 731-748.

JAVAID, A. (2016b) 'Male Rape, Stereotypes, and Unmet Needs: Hindering Recovery, Perpetuating Silence'. Violence and Gender, 3 (1): p. 7-13. [doi:10.1089/vio.2015.0039]

JAVAID, A. (2016c) 'Giving a Voice to the Voiceless: Police Responses to Male Rape'.Policing: A Journal of Policy and Practice.

JAVAID, A. (2017) Male Rape, Masculinities, and Sexualities: Understanding, Policing, and Overcoming Male Sexual Victimisation. Hampshire: Palgrave.

KASSING, L. R., Beesley, D., and Frey, L. L. (2005) 'Gender role conflict, homophobia, age and education as predictors of male rape myth acceptance.' Journal of Mental Health Counseling, 27(4): p. 311-28.

LEES, S. (1997) Ruling Passions. Sexual Violence, Reputation and the Law. Buckingham: Open University Press.

MACKINNON, C. (1989) Feminism Unmodified. Cambridge, Massachusetts: Harvard University Press.

MASON, J. (2002) Qualitative Researching. London: SAGE.

MESSERSCHMIDT, J. (1993) Masculinities and Crime: Critique and Reconceptualization of Theory.Maryland: Rowman and Littlefield.

MESSERSCHMIDT, J. (2000) 'Becoming "Real Men": Adolescent Masculinity Challenges and Sexual Violence.' Men and Masculinities, 2(3): p. 286-307. [doi:10.1177/1097184X00002003003]

MORSE, J. M. and Field, P. A. (1995)Qualitative Research Methods for Health Professionals. Thousand Oaks, CA: Sage.

NAFFINE, N. (1992) 'Windows on the legal mind: The evocation of rape in legal writings.Melbourne University Law Review, 18(4): p. 741-767.

OAKLEY, A. (1981) 'Interviewing Women: A Contradiction in Terms', in H. Roberts (ed.)Doing Feminist Research. New York: Routledge.

PASCOE, C. J., and Hollander, J. A. (2016) "Good Guys don't Rape: Gender, domination, and Mobilizing Rape". Gender and Society, 30(1): p. 67-79. [doi:10.1177/0891243215612707]

REINER, R. (2010) The Politics of the Police (4th edition). Oxford: Oxford University Press. [doi:10.1093/he/9780199283392.001.0001]

REINHARZ, S. (1992) Feminist Methods in Social Research New York: Oxford University Press.

RICHARDSON, D., and May, H. (1999) 'Deserving victims?: Sexual status and the social construction of violence'. Sociological Review, 47(2): p. 308-331.[doi:10.1111/1467-954X.00174]

ROGERS, P. (1998) 'Call for research into male rape'. Mental Health Practice, 1: p. 34.

RUMNEY, P. (2008) 'Policing male rape and sexual assault.' Journal of Criminal Law, 72(1): p. 67-86. 
RUMNEY, P. (2009) 'Gay male rape victims: law enforcement, social attitudes and barriers to recognition.'The International Journal of Human Rights, 13(2): p. 233-250. [doi:10.1080/13642980902758135]

STANLEY, L., and Wise, S. (1983) Breaking Out: Feminist Consciousness and Feminist Research London: Routledge and Kegan Paul.

STEMPLE, L., and Meyer, I. H. (2014) 'The Sexual Victimization of Men in America: New Data Challenge Old Assumptions.' American Journal of Public Health, 104(6): p. 19-26. [doi:10.2105/AJPH.2014.301946]

STERMAC, L., Sheridan, P. M., Davidson, A., and Dunn, S. (1996) 'Sexual assault of adult males.'Journal of Interpersonal Violence, 11(1): p. 52-65. [doi:10.1177/088626096011001004]

TEMKIN, J. (1982) 'Towards a Modern Law of Rape.'Modern Law Review, 45(4): p. 399-419. [doi:10.1111/j.1468-2230.1982.tb02487.x]

TEMKIN, J. (1987) Rape and the Legal Process. London: Sweet and Maxwell.

TEMKIN, J. and Krahe, B. (2008) Sexual Assault and the Justice Gap: A Question of Attitude North America: Hart Publishing.

TURCHIK, J. A., and Edwards, K. M. (2012) 'Myths About Male Rape: A Literature Review.'Psychology of Men \& Masculinity, 13(2): p. 211-226. [doi:10.1037/a0023207]

WALKER, J. (2004) A Study of Male Rape Survivors (PhD Thesis). University of Central Lancashire.

WALKER, J., Archer, J., and Davies, M. (2005) 'Effects of Rape on Men: A Descriptive Analysis.'Archives of Sexual Behavior, 34(1): p. 69-80. [doi:10.1007/s10508-005-1001-0]

WEISS, K. G. (2010) 'Male Sexual Victimization: Examining Men's Experiences of Rape and Sexual Assault.' Men and Masculinities, 12(3): p. 275-298. [doi:10.1177/1097184X08322632]

WEST, C., and Zimmerman, D. H. (1987) 'Doing Gender'. Gender and Society, 1(2): p. 125-151. [doi:10.1177/0891243287001002002]

ZALESKI, K. (2015) Understanding and Treating Military Sexual Trauma London: Springer. [doi:10.1007/978-3319-16607-0] 